\title{
An update on genetic frontotemporal dementia
}

\author{
Caroline V. Greaves ${ }^{1}$. Jonathan D. Rohrer ${ }^{1}$ (D)
}

Received: 20 April 2019 / Revised: 1 May 2019 / Accepted: 3 May 2019 / Published online: 22 May 2019

(c) The Author(s) 2019

\begin{abstract}
Frontotemporal dementia (FTD) is a highly heritable group of neurodegenerative disorders, with around $30 \%$ of patients having a strong family history. The majority of that heritability is accounted for by autosomal dominant mutations in the chromosome 9 open reading frame 72 (C9orf72), progranulin $(G R N)$, and microtubule-associated protein tau (MAPT) genes, with mutations more rarely seen in a number of other genes. This review will discuss the recent updates in the field of genetic FTD. Age at symptom onset in genetic FTD is variable with recently identified genetic modifiers including TMEM106B (in $G R N$ carriers particularly) and a polymorphism at a locus containing two overlapping genes LOC101929163 and C6orf10 (in C9orf72 carriers). Behavioural variant FTD (bvFTD) is the most common diagnosis in each of the genetic groups, although in C9orf72 carriers amyotrophic lateral sclerosis either alone, or with bvFTD, is also common. An atypical neuropsychiatric presentation is also seen in $C 9$ orf 72 carriers and family members of carriers are at greater risk of psychiatric disorders including schizophrenia and autistic spectrum disorders. Large natural history studies of presymptomatic genetic FTD are now underway both in Europe/Canada (GENFI - the Genetic FTD Initiative) and in the US (ARTFL/LEFFTDS study), collaborating together under the banner of the FTD Prevention Initiative (FPI). These studies are taking forward the validation of cognitive, imaging and fluid biomarkers that aim to robustly measure disease onset, staging and progression in genetic FTD. Grey matter changes on MRI and hypometabolism on FDG-PET are seen at least 10 years before symptom onset with white matter abnormalities seen earlier, but the pattern and exact timing of changes differ between different genetic groups. In contrast, tau PET has yet to show promise in genetic FTD. Three key fluid biomarkers have been identified so far that are likely to be helpful in clinical trials-CSF or blood neurofilament light chain levels (in all groups), CSF or blood progranulin levels (in GRN carriers) and CSF poly(GP) dipeptide repeat protein levels (in C9orf72 carriers). Increased knowledge about genetic FTD has led to more clinical presymptomatic genetic testing but this has not yet been mirrored in the development of either an accepted FTD-specific testing protocol or provision of appropriate psychological support mechanisms for those living through the at-risk phase. This will become even more relevant as disease-modifying therapy trials start in each of the genetic groups over the next few years.
\end{abstract}

Keywords Frontotemporal dementia $\cdot$ Neurogenetics $\cdot$ Tau $\cdot$ Progranulin $\cdot$ C9orf72 $\cdot$ Biomarkers

\section{Introduction}

Frontotemporal dementia (FTD) is a heterogeneous neurodegenerative disorder presenting with distinct changes in behaviour, language and motor function. Despite often being considered as a rare disease, FTD is probably the most common form of dementia experienced in people under the age

Jonathan D. Rohrer

j.rohrer@ucl.ac.uk

1 Department of Neurodegenerative Disease, Dementia Research Centre, UCL Queen Square Institute of Neurology, Queen Square, London WC1N 3BG, UK of 60 , with an estimated lifetime risk of 1 in 742 [1]. The behavioural variant (bvFTD) is characterised by changes in personality, while the language variant (known as primary progressive aphasia, PPA) is typically associated with progressive speech production or comprehension difficulties [2, 3]. People with FTD can also develop motor deficits, either amyotrophic lateral sclerosis (FTD-ALS) or Parkinsonism, in the latter case often with specific features of a corticobasal syndrome (CBS) or progressive supranuclear palsy (PSP) [4-6]. 


\section{Heritability, genes and phenotype}

\section{Heritability}

FTD is a highly heritable disorder but almost uniquely within the neurodegenerative disease spectrum, it is neither purely genetic (like Huntington's disease, HD) nor a mainly sporadic condition (like Alzheimer's disease) (Fig. 1). The extent of heritability of FTD has been the subject of a number of studies, with many of the initial investigations relying on the dichotomy between a 'present' or 'absent' family history. However, more nuanced family history scoring systems have been developed for FTD [7-9] revealing a complex picture of heritability. Using the modified Goldman score $[7,8]$ a strong family history [scores 1-3] was found in $31 \%$ [8], whilst using the Penn score, an equivalent strong family history [high or medium categories] was found in 26\% [9]. All of these studies show variability in heritability across the clinical phenotypes, e.g. a strong family history has been found in $48 \%$ of people with bvFTD but only $12 \%$ of people with PPA [9]. Heritability of the motor phenotypes is less clear (mainly due to small numbers in most studies), e.g. a strong family history has varied from 10 to $>40 \%$ in FTDALS $[8,10,11]$.

\section{Genes}

The majority of the heritability of FTD is accounted for by autosomal dominant mutations in three genes: progranulin
$(G R N)$, microtubule-associated protein tau $(M A P T)$ and chromosome 9 open reading frame 72 (C9orf72) [12, 13]. Each genetic group causes between $\sim 5$ and $10 \%$ of all FTD, with geographical variability in different case series (e.g. a predominance in Northern Italy and the Basque country of GRN mutations [14, 15]). Overall, C9orf72 seems to be the most common worldwide cause of genetic FTD, followed by $G R N$ and then MAPT. A list of pathogenic and other variants in these genes has been collated online in the AD\&FTD Mutation Database (http://www.molgen.ua.ac.be/ FTDmutations): $79 G R N$ and 45 MAPT pathogenic variants are currently described. However, a Pubmed search of mutations reported over the last 5 years in these genes identifies a further $35 G R N$ and $18 M A P T$ pathogenic variants not included in that database, i.e. 114 GRN and 63 MAPT mutations currently identified in total. This number excludes the majority of missense variants in GRN, many of which may be risk factors for Alzheimer's disease rather than a Mendelian cause of FTD, although identifying pathogenicity is not always easy [16].

In recent years, mutations in an increasing number of genes have been associated with autosomal dominant FTD: VCP (2004), CHMP2B (2005), TARDBP (2008), FUS (2009), SQSTMI (2012), CHCHDIO (2014), TBKI (2015), OPTN (2015), CCNF (2016), TIAl (2017). Cumulatively, they account for $<5 \%$ of all FTD, with most only found in a small number of families across the world. Recent studies have identified $T B K 1$ as probably the fourth most common genetic cause overall of FTD, accounting for between 1 and $2 \%$ of all cases (although the pathogenic nature of many of

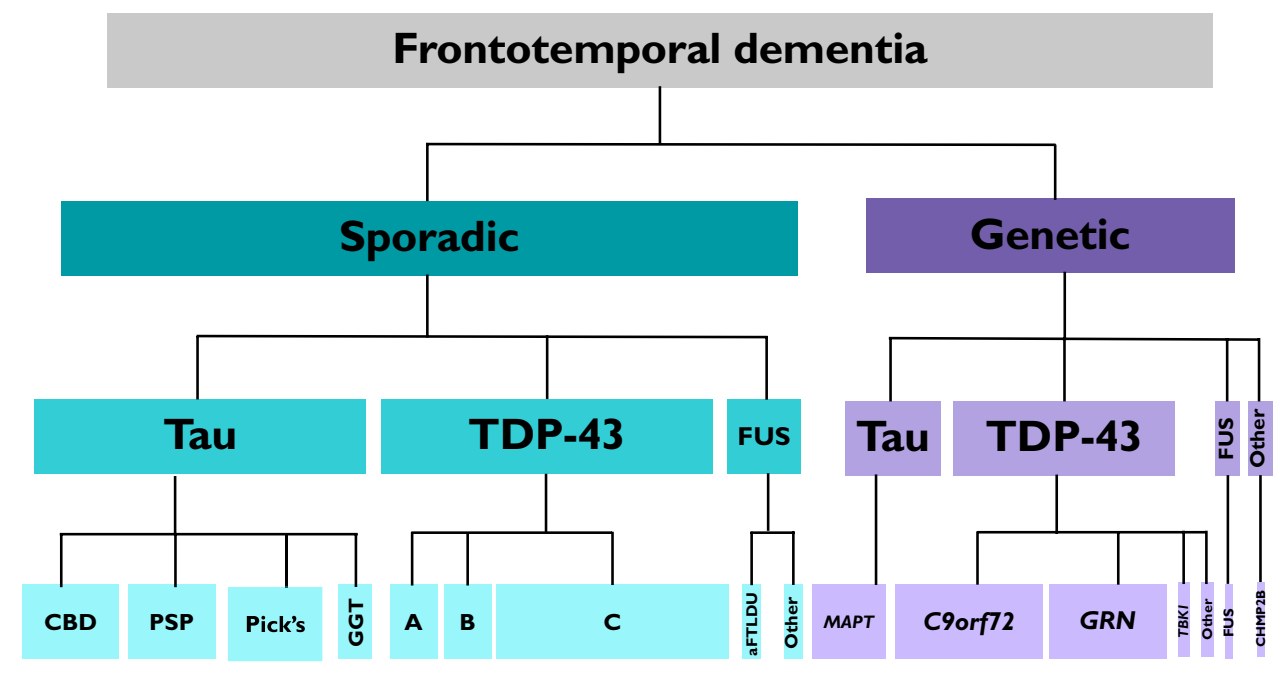

Fig. 1 The landscape of the frontotemporal dementia spectrum disorders. About $70 \%$ is sporadic with approximately equal numbers of TDP-43 proteinopathies and tauopathies (including corticobasal degeneration, $C B D$ progressive supranuclear palsy, PSP Pick's disease, $G G T$ globular glial tauopathy), and a smaller number of FUSopathies (including atypical frontotemporal lobar degeneration with ubiquitin inclusions, aFTLDU). About $30 \%$ is genetic with TDP43 proteinopathies being the commonest cause (mutations in $C 9$ orf72 (usually TDP-43 types A or B), GRN (type A), TBK1 (types A or B), $V C P$ (type D), SQSTM1, and TARDBP) then tauopathies (mutations in MAPT), FUSopathies (mutations in $F U S$ ) and other proteinopathies (mutations in $C H M P 2 B$ ) 
the reported missense variants remains unclear [17]). However, as with the major genetic groups, there is geographical variability: in a recent study of FTD in Sardinia, $8 \%$ of patients had a TARDBP mutation [18].

\section{Age at onset}

Age at symptom onset is variable in each of the genetic forms of FTD, with intrafamilial variability (even within the same generation) of at least a decade in some families (particularly $G R N$ ). Whilst MAPT mutations are fully penetrant in most cases, both GRN [19] and C9orf72 [20] mutations exhibit age-related penetrance with a small number of carriers in their 80s (and 90s) yet to develop symptoms. In both GRN and C9orf72 carriers, TMEM106B has been identified as a genetic modifier, the association being stronger with $G R N$ than with $C 9 \operatorname{orf72}$ [21]: a lower age at onset in $G R N$ may well be related to carrying the risk allele, with homozygous carriers of the protective allele rarely found in symptomatic GRN carriers, suggesting that this may be a factor in age-related penetrance [22]. Another recently identified modifier of disease risk in GRN carriers, GFRA2, did not seem to affect age at onset [22]. However, a study of $C 9$ orf 72 carriers identified a locus on chromosome six containing two overlapping genes (LOC101929163 and C6orf10) in which a polymorphism at rs9357140 was associated with age of onset: median age of onset in GG carriers was 6 years earlier than AA carriers [23]. The significance of the $C 9$ orf 72 repeat expansion length remains unclear, with no definitive evidence of an association with age of onset [24]. Little is known about factors that modify age at onset in the MAPT group, although a recent study suggested that ApoE $\varepsilon 4$ carriers had a lower age at onset in tauopathies including $M A P T$ mutations [25].

\section{Phenotype}

The most common clinical presentation of all genetic forms is bvFTD, but all phenotypes within the FTD spectrum are observed. MAPT mutation carriers may have prominent semantic impairment but that is rarely a presenting feature, nor are other forms of PPA; however, CBS and, in rare cases, PSP may both occur, although never FTD-ALS. In contrast, $G R N$ mutations can present as a PPA syndrome, either a nonfluent variant of PPA or a mixed phenotype, not clearly fitting into one of the three described subtypes [26]. CBS may occur either alone or in conjunction with PPA, but PSP and FTD-ALS are almost never seen. C9orf72 expansion carriers may have an atypical neuropsychiatric presentation of bvFTD with associated hallucinations or delusions $[27,28]$, and significantly, family members of $C 9$ orf 72 carriers have a greater risk of psychiatric disorders including autistic spectrum disorders, psychotic illnesses including schizophrenia, mood disorders and suicide [27]. Unlike the other two major genetic groups, C9orf72 expansions can cause FTD-ALS or ALS alone. PPA is a rare phenotype but is usually a nonfluent variant when present, and similarly parkinsonian disorders can occur but are infrequent as a presenting syndrome. Also unlike the other genetic groups, hyperkinetic movement disorders may occur, and $C 9$ orf 72 is said to be associated with a Huntington's disease-like phenotype on some occasions [29].

The phenotype in the other genetic groups is less clear. TBK1 mutations can cause bvFTD, PPA, CBS, FTD-ALS and ALS alone-this unique combination within a single family can be particularly suggestive of a $T B K 1$ mutation. $T B K 1$ and TARDBP mutations can both be associated with focal temporal lobe atrophy and a semantic variant PPA [18, 30, 31] an unusual genetic FTD phenotype as this variant of PPA is almost always sporadic.

\section{Natural history studies and biomarkers}

Until recently, clinical studies of genetic FTD have been small and single centre. However, the Genetic FTD Initiative (GENFI) started recruiting in 2012 and now encompasses 25 centres across Europe and Canada (http://www.genfi.org. uk). This is a natural history study with detailed phenotyping of both presymptomatic and symptomatic mutation carriers [32]. In the US, a similar study (ARTFL/LEFFTDS) has been running for the last few years. Collaboration across natural history studies of genetic FTD across the world has started through the creation of the FTD Prevention Initiative (FPI: http://www.genfi.org.uk/fpi.html), aiming to share information and inform future clinical trial design.

Much of the work being performed in these studies (and in other single centre investigations) over the last few years has aimed to develop validated biomarkers that robustly measure disease onset, staging and progression (Fig. 2). The following sections highlight recent work in this field.

\section{Cognition}

Neuropsychometric measures are abnormal in presymptomatic carriers around 5 years prior to expected symptom onset [32]. Whilst executive function deficits seem common across the different genetic groups, specific patterns of cognitive decline have been identified at a presymptomatic stage in MAPT, GRN and C9orf72 carriers [32]. A number of studies have now shown that MAPT carriers have both naming and episodic memory difficulties presymptomatically [32-34], consistent with early medial temporal lobe atrophy [32]. As mentioned above, whilst most people develop bvFTD, some develop PPA, and one study has shown that longitudinal preclinical decline on phonology and letter 
Fig. 2 Schematic of fluid, imaging and cognitive biomarker profiles across the lifespan of C9orf72, MAPT and GRN mutation carriers. $N f L$ neurofilament light chain, DTI diffusion tensor imaging, $W M$ white matter, $W M H$ white matter hyperintensities, $G M$ grey matter, $E F$ executive function, $V F$ verbal fluency, $M$ memory; $N$ naming

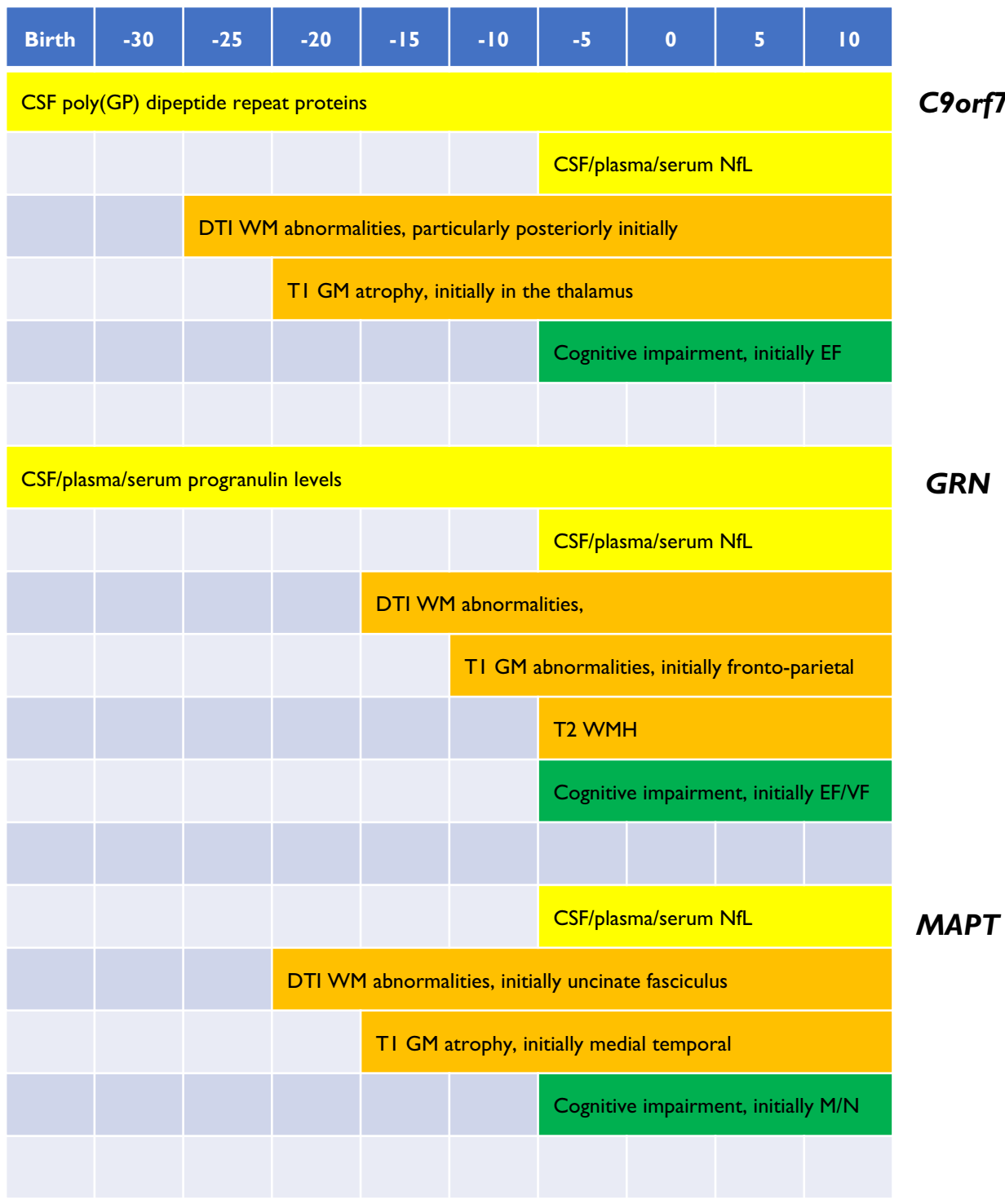

fluency tasks was predictive of conversion to a nonfluent variant PPA phenotype in GRN carriers [33].

\section{Neuropsychiatric and functional measures}

Validated measures of psychiatric symptoms or functional decline are limited in genetic FTD. The Neuropsychiatric Inventory (NPI) has been the most studied, although was not designed with FTD in mind, and does not include all relevant psychiatric symptoms that are seen in FTD [35]. The Cambridge Behavioural Inventory (CBI) has been used in the GENFI study and has shown changes in proximity to symptom onset [32], although as with many behavioural questionnaires there can be variability over time in FTD. More specific measures of particular symptoms such as loss of empathy (e.g. the Interpersonal Reactivity Index) or impaired self-monitoring (e.g. the Revised
Self-Monitoring Scale) have not yet been well studied in genetic FTD. In terms of measuring disease severity and decline in function over time, an adaptation of the Clinical Dementia Rating scale for FTD (commonly called the FTLD-CDR) shows promise in genetic FTD [35], as does the FTD Rating Scale (FRS) [36], but more detailed studies of these and other novel measures are required.

\section{Imaging}

Grey matter atrophy and hypometabolism both appear to occur at least 10 years before symptom onset in genetic FTD, whilst white matter tract abnormalities are seen earlier [37]. However, there is variability both in timing and location between the different genetic groups. 


\section{Grey matter atrophy (T1-weighted MRI)}

In presymptomatic $M A P T$ carriers, atrophy is present about 15 years prior to symptom onset in the anterior and medial temporal lobes, orbitofrontal lobe and insula [32, 38], whilst in $G R N$ carriers, presymptomatic atrophy can be observed in frontal, parietal, and insular cortex as well as the striatum around 10 years prior to symptom onset $[32,38]$. Symptomatic $G R N$ carriers commonly have a very asymmetrical pattern of brain atrophy, and this asymmetry can be observed around 5 years prior to onset [32]. C9orf72 mutation carriers appear to have earlier grey matter volume loss than the other two groups, before the age of 40 [39], and potentially more than 25 years prior to symptom onset [32]. This appears to be particularly focused on the posterior thalamus and its cortical connections [32, 38, 39].

Volumetric MRI studies of genetic FTD have particularly highlighted the importance of subcortical structures in the pathogenesis of FTD, and more recent work using novel postprocessing techniques has aimed to study the subregions within these structures, e.g. there are differential patterns of atrophy within hippocampal subregions in the different genetic groups: MAPT mutation carriers had involvement of CA1-4, C9orf72 expansion carriers CA4, CA1 and the dentate gyrus, and $G R N$ mutation carriers the presubiculum and subiculum [40].

There has been less focus on longitudinal investigation of grey matter atrophy; however, rates of atrophy vary between genetic groups with faster rates in $G R N$ mutation carriers during the symptomatic period (allowing measurement over short time periods: [41]) compared with the other groups. Around the time of symptom onset, there seems to be a more gradual progression of atrophy in MAPT mutation carriers but a rapid change in volume loss in GRN carriers [42].

Few studies have investigated disease staging of genetic FTD. One novel machine-learning methodology combining subtyping and staging identified genetic FTD subtypes and their stages over time from structural T1-weighted imaging alone [43]. Interestingly, whilst GRN and MAPT mutation carriers appeared to fall mainly into a single group, there were two distinct patterns of disease progression for $C 9$ orf 72 expansion carriers-it remains unclear pathophysiologically what differs between these two groups.

\section{White matter hyperintensities (T2-weighted MRI)}

A number of studies have now shown that white matter hyperintensities (which are generally an unusual finding in FTD) are characteristic of $G R N$ mutations [44, 45]. This is mainly in symptomatic mutation carriers (although for unclear reasons only a subset of patients), but there is also an association in presymptomatic mutation carriers with time from expected symptom onset [45]. Pathological studies of these white matter hyperintensities suggest that they are not vascular but are associated with prominent white matter microglial activation and microglial dystrophy [46].

\section{Hypometabolism (FDG-PET)}

Patterns of hypometabolism commonly mirror the pattern of grey matter atrophy in genetic FTD [47-51], with presymptomatic deficits also shown around 10 years prior to symptom onset.

\section{Structural connectivity (DTI)}

Changes in white matter integrity are commonly measured with diffusion tensor imaging (DTI), although newer techniques such as neurite orientation dispersion and density imaging (NODDI) have recently been developed. Studies in genetic FTD suggest that changes can be observed as far back as 30 years prior to symptom onset [52]. As with grey matter atrophy, there appear to be distinct patterns of early white matter involvement in the different groups: presymptomatic MAPT mutation carriers have alterations in the uncinate fasciculus and parahippocampal cingulum, while $G R N$ mutation carriers show involvement of the anterior and posterior internal capsule [52]. Presymptomatic C9orf72 expansion carriers have earlier white matter tract pathology, which occurs in posterior tracts such as the posterior thalamic radiation, the posterior corona radiata and the splenium of the corpus callosum [52,53]. A single study of NODDI suggests that it may be more sensitive than DTI for detecting early white matter change in $C 9$ orf 72 expansion carriers [54].

\section{Functional connectivity (resting-state fMRI)}

There have been fewer investigations of functional connectivity but small studies implicate particularly the salience network and a medial pulvinar thalamus-seeded network in presymptomatic C9orf72 expansion carriers [53], the default mode network in MAPT mutation carriers [55] and a frontoparietal network in $G R N$ mutation carriers [56-58].

\section{Tau PET}

Studies of novel radioligands developed to bind tau protein have so far not proven to be particularly helpful in FTD, binding much more strongly to paired helical filament (PHF)-tau found mainly in Alzheimer's disease than to other forms of tau found in the primary tauopathies. However, two particular MAPT mutations (V337M and R406W) are associated with PHF-tau and have shown strong binding with the AV1451 tracer [59-61]. Unfortunately, there is also offtarget binding of this tracer, with binding seen in non-tau 
diseases such as in $C 9$ orf72 expansions, where the major pathology is TDP-43 [62].

\section{Blood and CSF biomarkers}

The fluid biomarker field in genetic FTD has yet to identify many robust measures, e.g. neither CSF nor blood assays of tau or TDP-43 are yet to yield FTD-specific markers. However, recent work has identified three markers which will play an important role in forthcoming trials: neurofilament light chain (NfL), progranulin and poly(GP) dipeptide repeat proteins (DPRs).

Increased NfL levels (both in CSF and blood) reflect axonal damage and appear to be a measure of disease intensity, and predict progression and survival in genetic FTD $[63,64]$. Levels are highest in C9orf72-associated ALS and lowest in MAPT mutation carriers [64]. Longitudinal analysis of samples seems to suggest that levels change not long prior to symptom onset in genetic FTD, increasing by threeto fourfold during conversion [64]. Whilst an increase in NfL is not specific for FTD, and levels are increased in multiple neurological diseases, evidence from other diseases suggests that a decrease in levels could be a measure of successful disease modification in trials [65].

Low serum, plasma or CSF progranulin levels have almost perfect sensitivity and specificity for detecting pathogenic GRN mutations [66, 67]. Levels are low from the earliest time period of presymptomatic genetic FTD that they have been measured [during adulthood] and are relatively stable over time [67]. CSF and plasma levels are relatively poorly correlated ( $r=0.54: 67]$, and little work has been done to investigate measures that affect the variability of progranulin levels. This future research is important as increasing progranulin levels back towards normal levels (and therefore theoretically restoring normal progranulin function) will be a key biomarker for disease-modifying trials in $G R N$ carriers.

Increased poly $(\mathrm{GP})$ levels have been identified in the CSF of $C 9$ orf 72 expansion carriers both presymptomatically and symptomatically [68-70]. One study found slightly lower levels in presymptomatic expansion carriers compared with symptomatic carriers [70] but that has not been seen consistently. More work needs to be performed to understand variability further, but like NfL, decreasing levels of CSF poly(GP) post-treatment may be suggestive of disease modification in future trials.

A particular focus of biomarker research in genetic FTD is the development of markers of neuroinflammation. CHIT1 and YKL-40 are microglial markers that appear to be raised in symptomatic genetic FTD [71] with little evidence for a change during the presymptomatic period so far. In a small study, CSF sTREM2 levels were raised in GRN mutation carriers but not the other genetic groups [72].

\section{Clinical practice (Fig. 3)}

\section{Symptomatic genetic testing}

Testing in symptomatic patients with dementia has changed in recent years. Next-generation sequencing (NGS) panels are now available to test multiple genes at the same timethese have identified mutations causative of FTD pathology not just in those with an FTD clinical syndrome [73]. Issues that remain to be solved in clinical genetic testing include: how to decide the pathogenicity of certain variants (of which

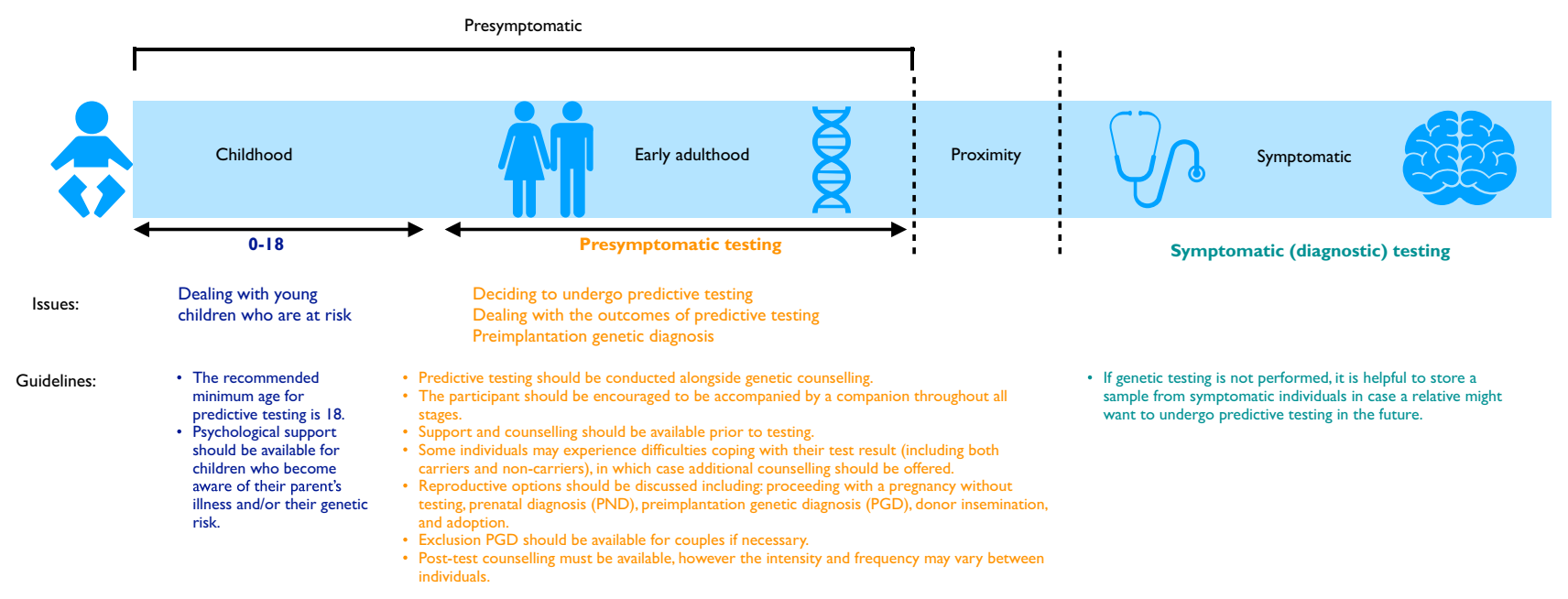

Fig. 3 Genetic testing, counselling and support through the timecourse of genetic FTD. There is commonly a period in proximity to symptom onset of FTD where subtle symptoms may be present but diagnostic criteria have not yet been met-this requires careful assessment and discussion 
more are now found because of NGS); the exact length at which $C 9$ orf 72 expansions become pathogenic (as intermediate length expansions are not clearly causative of disease [74]); and what to do when no mutation is found in a family with autosomal dominant FTD. In terms of this latter problem, many available NGS panels do not include the more recently discovered genes such as $T B K 1$ and we have identified mutations in these genes by exome sequencing in those with negative NGS and C9orf72 sequencing [30]. However there are still a small number of families with a strong family history of FTD without a known genetic mutation. We offer genetic testing in our clinic to all those with bvFTD, even in the absence of a family history, as mutations have been found in around $10 \%$ of apparently sporadic cases of FTD [75]. In the other FTD clinical phenotypes, where the risk is lower of a genetic cause, we offer testing on an individual basis, mainly in those with a strong family history, but the identification of a PPA syndrome not fitting criteria for one of the three described subtypes is a red flag for consideration of testing (with the expectation of potentially finding a $G R N$ mutation) $[26,76]$.

\section{Presymptomatic genetic testing}

Once a causal mutation has been established in a symptomatic relative, the option of predictive genetic testing can be raised with at-risk family members. While potential treatments for FTD are still lacking, appropriate clinical care for presymptomatic populations is integral. The genetic counselling and support systems in place lag far behind those seen in other neurodegenerative disorders. Whilst in practice the HD predictive genetic testing protocol is currently used as the gold standard [77], there are a number of key distinctions between HD and FTD which mean that the HD protocol may not be appropriate for the FTD population [78], including age-related penetrance, unpredictable age at onset of symptoms, and phenotypic heterogeneity. Similarly, access, experiences and attitudes towards predictive testing can vary depending on location [79], and future development of an FTD-specific protocol may be more suitable.

The HD predictive guidelines stress the importance of psychological evaluation in presymptomatic carriers, with others suggesting that psychological assessment is a necessary process for identifying an individual's risk of experiencing an adverse psychological reaction to presymptomatic testing [80]. There remain a large proportion of individuals who live at-risk of FTD who decide against predictive testing-probably about $70-80 \%$ of this population [32]. These individuals receive little or no support as many will not have even been through genetic counselling, and little work has been done to identify their psychological needs. Initial research does suggest that rates of depression and mood disorders are higher even in non-carriers within FTD families [81]. One method of helping such individuals is the provision of specific support groups aimed at providing peer support and information about the at-risk period-the familial FTD support group in the UK is one such example (http:// www.raredementiasupport.org/fftd/). Specific interventions at an appropriate time such as cognitive behaviour therapy or mindfulness have yet to be trialled.

\section{Clinical trials and emerging therapies}

There are currently no disease-modifying therapies for genetic FTD but trials are now underway or planned in each of the three main genetic FTD groups. Antisense oligonucleotide therapy shows promise for both C9orf72 expansions [82] and MAPT mutations [83], whilst AAV gene therapy is a potential avenue for disease modification in $G R N$ carriers $[84,85]$, although one study in a mouse model showed evidence of T cell-mediated toxicity [85]. Small molecule therapies and tau monoclonal antibodies are also being developed for tauopathies (with a potential for use in MAPT mutations) [86], and other options for $G R N$ mutations include modification of proteins such as sortilin and HDAC that lead to increased $G R N$ levels $[87,88]$.

\section{Summary}

Much has been learnt about genetic FTD in the last decade, with the majority of autosomal dominant FTD now accounted for. The development of collaborative international multicentre natural history studies in GENFI and ARTFL/LEFFTDS has brought together researchers and families, and has helped to set the background for clinical trials that are now getting started and being planned. An associated support network for those living at-risk of genetic FTD is important and there is work to be done in improving this; but with the advent of specific gene-targeted therapeutics, there is hope in the community for the future outlook.

\section{Compliance with ethical standards}

Conflicts of interest We have no conflicts of interest.

Open Access This article is distributed under the terms of the Creative Commons Attribution 4.0 International License (http://creativeco mmons.org/licenses/by/4.0/), which permits unrestricted use, distribution, and reproduction in any medium, provided you give appropriate credit to the original author(s) and the source, provide a link to the Creative Commons license, and indicate if changes were made. 


\section{References}

1. Coyle-Gilchrist IT, Dick KM, Patterson K, Vázquez Rodríquez P, Wehmann E, Wilcox A, Lansdall CJ, Dawson KE, Wiggins J, Mead S, Brayne C, Rowe JB (2016) Prevalence, characteristics, and survival of frontotemporal lobar degeneration syndromes. Neurology 86(18):1736-1743

2. Rascovsky K, Hodges JR, Knopman D, Mendez MF, Kramer JH, Neuhaus J, van Swieten JC, Seelaar H, Dopper EG, Onyike CU, Hillis AE, Josephs KA, Boeve BF, Kertesz A, Seeley WW, Rankin KP, Johnson JK, Gorno-Tempini ML, Rosen H, Prioleau-Latham CE, Lee A, Kipps CM, Lillo P, Piguet O, Rohrer JD, Rossor MN, Warren JD, Fox NC, Galasko D, Salmon DP, Black SE, Mesulam M, Weintraub S, Dickerson BC, DiehlSchmid J, Pasquier F, Deramecourt V, Lebert F, Pijnenburg Y, Chow TW, Manes F, Grafman J, Cappa SF, Freedman M, Grossman M, Miller BL (2011) Sensitivity of revised diagnostic criteria for the behavioural variant of frontotemporal dementia. Brain 134(Pt 9):2456-2477

3. Gorno-Tempini ML, Hillis AE, Weintraub S, Kertesz A, Mendez M, Cappa SF, Ogar JM, Rohrer JD, Black S, Boeve BF, Manes F, Dronkers NF, Vandenberghe R, Rascovsky K, Patterson K, Miller BL, Knopman DS, Hodges JR, Mesulam MM, Grossman M (2011) Classification of primary progressive aphasia and its variants. Neurology 76(11):1006-1014

4. Strong MJ, Abrahams S, Goldstein LH, Woolley S, Mclaughlin P, Snowden J, Mioshi E, Roberts-South A, Benatar M, HortobáGyi T, Rosenfeld J, Silani V, Ince PG, Turner MR (2017) Amyotrophic lateral sclerosis-frontotemporal spectrum disorder (ALS-FTSD): revised diagnostic criteria. Amyotroph Later Scler Frontotempor Degener 18(3-4):153-174

5. Armstrong MJ, Litvan I, Lang AE, Bak TH, Bhatia KP, Borroni B, Boxer AL, Dickson DW, Grossman M, Hallett M, Josephs KA, Kertesz A, Lee SE, Miller BL, Reich SG, Riley DE, Tolosa E, Tröster AI, Vidailhet M, Weiner WJ (2013) Criteria for the diagnosis of corticobasal degeneration. Neurology 80(5):496-503

6. Höglinger GU, Respondek G, Stamelou M, Kurz C, Josephs KA, Lang AE, Mollenhauer B, Müller U, Nilsson C, Whitwell JL, Arzberger T, Englund E, Gelpi E, Giese A, Irwin DJ, Meissner WG, Pantelyat A, Rajput A, van Swieten JC, Troakes C, Antonini A, Bhatia KP, Bordelon Y, Compta Y, Corvol JC, Colosimo C, Dickson DW, Dodel R, Ferguson L, Grossman M, Kassubek J, Krismer F, Levin J, Lorenzl S, Morris HR, Nestor P, Oertel WH, Poewe W, Rabinovici G, Rowe JB, Schellenberg GD, Seppi K, van Eimeren T, Wenning GK, Boxer AL, Golbe LI, Litvan I, Movement Disorder Society-endorsed PSPStudy Group (2017) Clinical diagnosis of progressive supranuclear palsy: the movement disorder society criteria. Mov Disord 32(6):853-864

7. Beck J, Rohrer JD, Campbell T, Isaacs A, Morrison KE, Goodall EF, Warrington EK, Stevens J, Revesz T, Holton J, Al-Sarraj S, King A, Scahill R, Warren JD, Fox NC, Rossor MN, Collinge J, Mead S (2008) A distinct clinical, neuropsychological and radiological phenotype is associated with progranulin gene mutations in a large UK series. Brain 131(Pt 3):706-720

8. Rohrer JD, Guerreiro R, Vandrovcova J, Uphill J, Reiman D, Beck J, Isaacs AM, Authier A, Ferrari R, Fox NC, Mackenzie IRA (2009) The heritability and genetics of frontotemporal lobar degeneration. Neurology 73:1451-1456

9. Wood EM, Falcone D, Suh E, Irwin DJ, Chen-Plotkin AS, Lee EB, Xie SX, Van Deerlin VM, Grossman M (2013) Development and validation of pedigree classification criteria for frontotemporal lobar degeneration. JAMA Neurol 70(11):1411-1417

10. Goldman JS, Farmer JM, Wood EM, Johnson JK, Boxer A, Neuhaus J, Lomen-Hoerth C, Wilhelmsen KC, Lee VM, Grossman
M, Miller BL (2005) Comparison of family histories in FTLD subtypes and related tauopathies. Neurology 65(11):1817-1819

11. Po K, Leslie FV, Gracia N, Bartley L, Kwok JB, Halliday GM, Hodges JR, Burrell JR (2014) Heritability in frontotemporal dementia: more missing pieces. J Neurol 261(11):2170-2177

12. Mahoney CJ, Beck J, Rohrer JD, Lashley T, Mok K, Shakespeare T, Yeatman T, Warrington EK, Schott JM, Fox NC, Rossor MN, Hardy J, Collinge J, Revesz T, Mead S, Warren JD (2012) Frontotemporal dementia with the C9ORF72 hexanucleotide repeat expansion: clinical, neuroanatomical and neuropathological features. Brain 135(Pt 3):736-750

13. Snowden JS, Rollinson S, Thompson JC, Harris JM, Stopford CL, Richardson AM, Jones M, Gerhard A, Davidson YS, Robinson A, Gibbons L, Hu Q, DuPlessis D, Neary D, Mann DM, PickeringBrown SM (2012) Distinct clinical and pathological characteristics of frontotemporal dementia associated with C9ORF72mutations. Brain 135(Pt 3):693-708

14. Borroni B, Bonvicini C, Galimberti D, Tremolizzo L, Papetti A, Archetti S, Turla M, Alberici A, Agosti C, Premi E, Appollonio I, Rainero I, Ferrarese C, Gennarelli M, Scarpini E, Padovani A (2011) Founder effect and estimation of the age of the progranulin Thr272fs mutation in 14 Italian pedigrees with frontotemporal lobar degeneration. Neurobiol Aging 32(3):555.e1-555.e8

15. Barandiaran M, Estanga A, Moreno F, Indakoetxea B, Alzualde A, Balluerka N, Martí Massó JF, de López Munain A (2012) Neuropsychological features of asymptomatic c.709-1G > A progranulin mutation carriers. J Int Neuropsychol Soc 18(6):1086-1090

16. Redaelli V, Rossi G, Maderna E, Kovacs GG, Piccoli E, Caroppo P, Cacciatore F, Spinello S, Grisoli M, Sozzi G, Salmaggi A, Tagliavini F, Giaccone G (2018) Alzheimer neuropathology without frontotemporal lobar degeneration hallmarks (TAR DNA-binding protein 43 inclusions) in missense progranulin mutation Cys139Arg. Brain Pathol 28(1):72-76

17. de Majo M, Topp SD, Smith BN, Nishimura AL, Chen HJ, Gkazi AS, Miller J, Wong CH, Vance C, Baas F, Ten Asbroek ALMA, Kenna KP, Ticozzi N, Redondo AG, Esteban-Pérez J, Tiloca C, Verde F, Duga S, Morrison KE, Shaw PJ, Kirby J, Turner MR, Talbot K, Hardiman O, Glass JD, de Belleroche J, Gellera C, Ratti A, Al-Chalabi A, Brown RH, Silani V, Landers JE, Shaw CE (2018) ALS-associated missense and nonsense TBK1 mutations can both cause loss of kinase function. Neurobiol Aging 71:266. e1-266.e10

18. Floris G, Borghero G, Cannas A, Di Stefano F, Murru MR, Corongiu D, Cuccu S, Tranquilli S, Cherchi MV, Serra A, Loi G, Marrosu MG, Chio A, Marrosu F (2015) Clinical phenotypes and radiological findings in frontotemporal dementia related to TARDBP mutations. J Neurol 262:375-384

19. Gass J, Cannon A, Mackenzie IR, Boeve B, Baker M, Adamson J, Crook R, Melquist S, Kuntz K, Petersen R, Josephs K, PickeringBrown SM, Graff-Radford N, Uitti R, Dickson D, Wszolek Z, Gonzalez J, Beach TG, Bigio E, Johnson N, Weintraub S, Mesulam M, White CL 3rd, Woodruff B, Caselli R, Hsiung GY, Feldman H, Knopman D, Hutton M, Rademakers R (2006) Mutations in progranulin are a major cause of ubiquitin-positive frontotemporal lobar degeneration. Hum Mol Genet 15(20):2988-3001

20. Murphy NA, Arthur KC, Tienari PJ, Houlden H, Chiò A, Traynor BJ (2017) Age-related penetrance of the C9orf72 repeat expansion. Sci Rep 7(1):2116

21. Nicholson AM, Rademakers R (2016) What we know about TMEM106B in neurodegeneration. Acta Neuropathol 132(5):639-651

22. Pottier C, Zhou X, Perkerson RB 3rd, Baker M, Jenkins GD, Serie DJ, Ghidoni R, Benussi L, Binetti G, López de Munain A, Zulaica M, Moreno F, Le Ber I, Pasquier F, Hannequin D, Sánchez-Valle R, Antonell A, Lladó A, Parsons TM, Finch NA, Finger EC, Lippa CF, Huey ED, Neumann M, Heutink P, Synofzik M, Wilke C, 
Rissman RA, Slawek J, Sitek E, Johannsen P, Nielsen JE, Ren Y, van Blitterswijk M, DeJesus-Hernandez M, Christopher E, Murray ME, Bieniek KF, Evers BM, Ferrari C, Rollinson S, Richardson A, Scarpini E, Fumagalli GG, Padovani A, Hardy J, Momeni P, Ferrari R, Frangipane F, Maletta R, Anfossi M, Gallo M, Petrucelli L, Suh E, Lopez OL, Wong TH, van Rooij JGJ, Seelaar H, Mead S, Caselli RJ, Reiman EM, Noel Sabbagh M, Kjolby M, Nykjaer A, Karydas AM, Boxer AL, Grinberg LT, Grafman J, Spina S, Oblak A, Mesulam MM, Weintraub S, Geula C, Hodges JR, Piguet O, Brooks WS, Irwin DJ, Trojanowski JQ, Lee EB, Josephs KA, Parisi JE, Ertekin-Taner N, Knopman DS, Nacmias B, Piaceri I, Bagnoli S, Sorbi S, Gearing M, Glass J, Beach TG, Black SE, Masellis M, Rogaeva E, Vonsattel JP, Honig LS, Kofler J, Bruni AC, Snowden J, Mann D, Pickering-Brown S, DiehlSchmid J, Winkelmann J, Galimberti D, Graff C, Öijerstedt L, Troakes C, Al-Sarraj S, Cruchaga C, Cairns NJ, Rohrer JD, Halliday GM, Kwok JB, van Swieten JC, White CL 3rd, Ghetti B, Murell JR, Mackenzie IRA, Hsiung GR, Borroni B, Rossi G, Tagliavini F, Wszolek ZK, Petersen RC, Bigio EH, Grossman M, Van Deerlin VM, Seeley WW, Miller BL, Graff-Radford NR, Boeve BF, Dickson DW, Biernacka JM, Rademakers R (2018) Potential genetic modifiers of disease risk and age at onset in patients with frontotemporal lobar degeneration and GRN mutations: a genomewide association study. Lancet Neurol 17(6):548-558

23. Zhang M, Ferrari R, Tartaglia MC, Keith J, Surace EI, Wolf U, Sato C, Grinberg M, Liang Y, Xi Z, Dupont K, McGoldrick P, Weichert A, McKeever PM, Schneider R, McCorkindale MD, Manzoni C, Rademakers R, Graff-Radford NR, Dickson DW, Parisi JE, Boeve BF, Petersen RC, Miller BL, Seeley WW, van Swieten JC, van Rooij J, Pijnenburg Y, van der Zee J, Van Broeckhoven C, Le Ber I, Van Deerlin V, Suh E, Rohrer JD, Mead S, Graff C, Oijerstedt L, Pickering-Brown S, Rollinson S, Rossi G, Tagliavini F, Brooks WS, Dobson-Stone C, Halliday GM, Hodges JR, Piguet O, Binetti G, Benussi L, Ghidoni R, Nacmias B, Sorbi S, Bruni AC, Galimberti D, Scarpini E, Rainero I, Rubino E, Clarimon J, Lleo A, Ruiz A, Hernandez I, Pastor P, Diez-Fairen M, Borroni B, Pasquier F, Deramecourt V, Lebouvier T, Perneczky R, Diehl-Schmid J, Grafman J, Huey ED, Mayeux R, Nalls MA, Hernandez D, Singleton A, Momeni P, Zeng Z, Hardy J, Robertson J, Zinman L, Rogaeva E, International FTDGC (2018) A C6orf10/ LOC101929163 locus is associated with age of onset in C9orf72 carriers. Brain 141:2895-2907

24. Fournier C, Barbier M, Camuzat A, Anquetil V, Lattante S, Clot F, Cazeneuve C, Rinaldi D, Couratier P, Deramecourt V, Sabatelli M, Belliard S, Vercelletto M, Forlani S, Jornea L, French Clinical and Genetic Research Network on FTLD/FTLD-ALS; PREVDEMALS and FTLD-Exome Study Groups, Leguern E, Brice A, Le Ber I (2019) Relations between C9orf72 expansion size in blood, age at onset, age at collection and transmission across generations in patients and presymptomatic carriers. Neurobiol Aging 74:234. e1-234.e8

25. Koriath C, Lashley T, Taylor W, Druyeh R, Dimitriadis A, Denning N, Williams J, Warren JD, Fox NC, Schott JM, Rowe JB, Collinge J, Rohrer JD, Mead S (2019) ApoE4 lowers age at onset in patients with frontotemporal dementia and tauopathy independent of amyloid- $\beta$ copathology. Alzheimers Dement (Amst) 11:277-280

26. Rohrer JD, Crutch SJ, Warrington EK, Warren JD (2010) Progranulin-associated primary progressive aphasia: a distinct phenotype? Neuropsychologia 48(1):288-297

27. Devenney EM, Ahmed RM, Halliday G, Piguet O, Kiernan MC, Hodges JR (2018) Psychiatric disorders in C9orf72 kindreds: study of 1,414 family members. Neurology 91:e1498-e1507

28. Ducharme S, Bajestan S, Dickerson BC, Voon V (2017) Psychiatric presentations of $\mathrm{C} 9$ orf 72 mutation: what are the diagnostic implications for clinicians? J Neuropsychiatry Clin Neurosci 29:195-205

29. Bourinaris T, Houlden $\mathrm{H}$ (2018) C9orf72 and its relevance in Parkinsonism and movement disorders: a comprehensive review of the literature. Mov Disord Clin Pract 5(6):575-585

30. Koriath CA, Bocchetta M, Brotherhood E, Woollacott IO, Norsworthy P, Simón-Sánchez J, Blauwendraat C, Dick KM, Gordon E, Harding SR, Fox NC, Crutch S, Warren JD, Revesz T, Lashley T, Mead S, Rohrer JD (2016) The clinical, neuroanatomical, and neuropathologic phenotype of $T B K 1$-associated frontotemporal dementia: a longitudinal case report. Alzheimers Dement (Amst) 6:75-81

31. Caroppo P, Camuzat A, De Septenville A, Couratier P, Lacomblez L, Auriacombe S, Flabeau O, Jornéa L, Blanc F, Sellal F, Cretin B, Meininger V, Fleury MC, Couarch P, Dubois B, Brice A, Le Ber I (2015) Semantic and nonfluent aphasic variants, secondarily associated with amyotrophic lateral sclerosis, are predominant frontotemporal lobar degeneration phenotypes in TBK1 carriers. Alzheimers Dement (Amst) 1(4):481-486

32. Rohrer JD, Nicholas JM, Cash DM, van Swieten J, Dopper E, Jiskoot L, van Minkelen R, Rombouts SA, Cardoso MJ, Clegg S, Espak M, Mead S, Thomas DL, De Vita E, Masellis M, Black SE, Freedman M, Keren R, MacIntosh BJ, Rogaeva E, Tang-Wai D, Tartaglia MC, Laforce R Jr, Tagliavini F, Tiraboschi P, Redaelli V, Prioni S, Grisoli M, Borroni B, Padovani A, Galimberti D, Scarpini E, Arighi A, Fumagalli G, Rowe JB, Coyle-Gilchrist I, Graff C, Fallstrom M, Jelic V, Stahlbom AK, Andersson C, Thonberg H, Lilius L, Frisoni GB, Pievani M, Bocchetta M, Benussi L, Ghidoni R, Finger E, Sorbi S, Nacmias B, Lombardi G, Polito C, Warren JD, Ourselin S, Fox NC, Rossor MN, Binetti G (2015) Presymptomatic cognitive and neuroanatomical changes in genetic frontotemporal dementia in the genetic frontotemporal dementia initiative (GENFI) study: a cross-sectional analysis. Lancet Neurol $14: 253-262$

33. Jiskoot LC, Panman JL, van Asseldonk L, Franzen S, Meeter LHH, Donker Kaat L, van der Ende EL, Dopper EGP, Timman R, van Minkelen R, van Swieten JC, van den Berg E, Papma JM (2018) Longitudinal cognitive biomarkers predicting symptom onset in presymptomatic frontotemporal dementia. J Neurol 265:1381-1392

34. Cheran G, Wu L, Lee S, Manoochehri M, Cines S, Fallon E, Lynch T, Heidebrink J, Paulson H, Goldman J, Huey E, Cosentino S (2019) Cognitive indicators of preclinical behavioral variant frontotemporal dementia in MAPT carriers. J Int Neuropsychol Soc 25(2):184-194

35. Premi E, Gualeni V, Costa P, Cosseddu M, Gasparotti R, Padovani A, Borroni B (2016) Looking for measures of disease severity in the frontotemporal dementia continuum. J Alzheimers Dis 52(4):1227-1235

36. Mioshi E, Hsieh S, Savage S, Hornberger M, Hodges JR (2010) Clinical staging and disease progression in frontotemporal dementia. Neurology 74(20):1591-1597

37. Meeter LH, Kaat LD, Rohrer JD, van Swieten JC (2017) Imaging and fluid biomarkers in frontotemporal dementia. Nat Rev Neurol 13:406-419

38. Cash DM, Bocchetta M, Thomas DL, Dick KM, van Swieten JC, Borroni B, Galimberti D, Masellis M, Tartaglia MC, Rowe JB, Graff C, Tagliavini F, Frisoni GB, Laforce R Jr, Finger E, de Mendonca A, Sorbi S, Rossor MN, Ourselin S, Rohrer JD, Genetic Ftd Initiative G (2018) Patterns of gray matter atrophy in genetic frontotemporal dementia: results from the GENFI study. Neurobiol Aging 62:191-196

39. Bertrand A, Wen J, Rinaldi D, Houot M, Sayah S, Camuzat A, Fournier C, Fontanella S, Routier A, Couratier P, Pasquier F, Habert MO, Hannequin D, Martinaud O, Caroppo P, Levy R, Dubois B, Brice A, Durrleman S, Colliot O, Le Ber I, Predict 
to Prevent Frontotemporal Lobar Degeneration and Amyotrophic Lateral Sclerosis (PREV-DEMALS) Study Group (2018) Early cognitive, structural, and microstructural changes in presymptomatic C9orf72 carriers younger than 40 years. JAMA Neurol 75(2):236-245

40. Bocchetta M, Iglesias JE, Scelsi MA, Cash DM, Cardoso MJ, Modat M, Altmann A, Ourselin S, Warren JD, Rohrer JD (2018) Hippocampal subfield volumetry: differential pattern of atrophy in different forms of genetic frontotemporal dementia. J Alzheimers Dis 64:497-504

41. Sha SJ, Miller ZA, Min SW, Zhou Y, Brown J, Mitic LL, Karydas A, Koestler M, Tsai R, Corbetta-Rastelli C, Lin S, Hare E, Fields S, Fleischmann KE, Powers R, Fitch R, Martens LH, Shamloo M, Fagan AM, Farese RV Jr, Pearlman R, Seeley W, Miller BL, Gan L, Boxer AL (2017) An 8-week, open-label, dose-finding study of nimodipine for the treatment of progranulin insufficiency from GRN gene mutations. Alzheimers Dement (N Y) 3(4):507-512

42. Jiskoot LC, Panman JL, Meeter LH, Dopper EGP, Donker Kaat L, Franzen S, van der Ende EL, van Minkelen R, Rombouts SARB, Papma JM, van Swieten JC (2019) Longitudinal multimodal MRI as prognostic and diagnostic biomarker in presymptomatic familial frontotemporal dementia. Brain 142(1):193-208

43. Young AL, Marinescu RV, Oxtoby NP, Bocchetta M, Yong K, Firth NC, Cash DM, Thomas DL, Dick KM, Cardoso J, van Swieten J, Borroni B, Galimberti D, Masellis M, Tartaglia MC, Rowe JB, Graff C, Tagliavini F, Frisoni GB, Laforce R Jr, Finger E, de Mendonça A, Sorbi S, Warren JD, Crutch S, Fox NC, Ourselin S, Schott JM, Rohrer JD, Alexander DC, Genetic FTD Initiative (GENFI); Alzheimer's Disease Neuroimaging Initiative (ADNI) (2018) Uncovering the heterogeneity and temporal complexity of neurodegenerative diseases with subtype and stage inference. Nat Commun 9(1):4273

44. Caroppo P, Le Ber I, Camuzat A, Clot F, Naccache L, Lamari F, De Septenville A, Bertrand A, Belliard S, Hannequin D, Colliot O, Brice A (2014) Extensive white matter involvement in patients with frontotemporal lobar degeneration: think progranulin. JAMA Neurol 71(12):1562-1566

45. Sudre CH, Bocchetta M, Cash D, Thomas DL, Woollacott I, Dick KM, van Swieten J, Borroni B, Galimberti D, Masellis M, Tartaglia MC, Rowe JB, Graff C, Tagliavini F, Frisoni G, Laforce R Jr, Finger E, de Mendonça A, Sorbi S, Ourselin S, Cardoso MJ, Rohrer JD, Genetic FTD Initiative, GENFI (2017) White matter hyperintensities are seen only in $G R N$ mutation carriers in the GENFI cohort. Neuroimage Clin 15:171-180

46. Woollacott IOC, Bocchetta M, Sudre CH, Ridha BH, Strand C, Courtney R, Ourselin S, Cardoso MJ, Warren JD, Rossor MN, Revesz T, Fox NC, Holton JL, Lashley T, Rohrer JD (2018) Pathological correlates of white matter hyperintensities in a case of progranulin mutation associated frontotemporal dementia. Neurocase 24(3):166-174

47. Deters KD, Risacher SL, Farlow MR, Unverzagt FW, Kareken DA, Hutchins GD, Yoder KK, Murrell JR, Spina S, Epperson F, Gao S, Saykin AJ, Ghetti B (2014) Cerebral hypometabolism and grey matter density in MAPT intron 10+ 3 mutation carriers. Am J Neurodegener Dis 3:103-114

48. Caroppo P, Habert MO, Durrleman S, Funkiewiez A, Perlbarg V, Hahn V, Bertin H, Gaubert M, Routier A, Hannequin D, Deramecourt V, Pasquier F, Rivaud-Pechoux S, Vercelletto M, Edouart G, Valabregue R, Lejeune P, Didic M, Corvol JC, Benali H, Lehericy S, Dubois B, Colliot O, Brice A, Le Ber I, Psg Predict (2015) Lateral temporal lobe: an early imaging marker of the presymptomatic GRN disease? J Alzheimers Dis 47:751-759

49. Jacova C, Hsiung GY, Tawankanjanachot I, Dinelle K, McCormick S, Gonzalez M, Lee H, Sengdy P, Bouchard-Kerr P, Baker M, Rademakers R, Sossi V, Stoessl AJ, Feldman HH, Mackenzie IR
(2013) Anterior brain glucose hypometabolism predates dementia in progranulin mutation carriers. Neurology 81:1322-1331

50. Diehl-Schmid J, Licata A, Goldhardt O, Förstl H, Yakushew I, Otto M, Anderl-Straub S, Beer A, Ludolph AC, Landwehrmeyer GB, Levin J, Danek A, Fliessbach K, Spottke A, Fassbender K, Lyros E, Prudlo J, Krause BJ, Volk A, Edbauer D, Schroeter ML, Drzezga A, Kornhuber J, Lauer M, FTLDc Study Group, Grimmer T (2019) FDG-PET underscores the key role of the thalamus in frontotemporal lobar degeneration caused by C9ORF72 mutations. Transl Psychiatry 9(1):54

51. Cistaro A, Pagani M, Montuschi A, Calvo A, Moglia C, Canosa A, Restagno G, Brunetti M, Traynor BJ, Nobili F, Carrara G, Fania P, Lopiano L, Valentini MC, Chio A (2014) The metabolic signature of C9ORF72-related ALS: fDG PET comparison with nonmutated patients. Eur J Nucl Med Mol Imaging 41:844-852

52. Jiskoot LC, Bocchetta M, Nicholas JM, Cash DM, Thomas D, Modat M, Ourselin S, Rombouts S, Dopper EGP, Meeter LH, Panman JL, van Minkelen R, van der Ende EL, Donker Kaat L, Pijnenburg YAL, Borroni B, Galimberti D, Masellis M, Tartaglia MC, Rowe J, Graff C, Tagliavini F, Frisoni GB, Laforce R Jr, Finger E, de Mendonca A, Sorbi S, Genetic Frontotemporal dementia I, Papma JM, van Swieten JC, Rohrer JD (2018) Presymptomatic white matter integrity loss in familial frontotemporal dementia in the GENFI cohort: a cross-sectional diffusion tensor imaging study. Ann Clin Transl Neurol 5:1025-1036

53. Lee SE, Sias AC, Mandelli ML, Brown JA, Brown AB, Khazenzon AM, Vidovszky AA, Zanto TP, Karydas AM, Pribadi M, Dokuru D, Coppola G, Geschwind DH, Rademakers R, GornoTempini ML, Rosen HJ, Miller BL, Seeley WW (2016) Network degeneration and dysfunction in presymptomatic C $9 O R F 72$ expansion carriers. Neuroimage Clin 14:286-297

54. Wen J, Zhang H, Alexander DC, Durrleman S, Routier A, Rinaldi D, Houot M, Couratier P, Hannequin D, Pasquier F, Zhang J, Colliot O, Le Ber I, Bertrand A, Predict to Prevent Frontotemporal Lobar Degeneration and Amyotrophic Lateral Sclerosis (PREVDEMALS) Study Group (2018) Neurite density is reduced in the presymptomatic phase of $C 9$ orf72 disease. J Neurol Neurosurg Psychiatry 90(4):387-394

55. Whitwell JL, Josephs KA, Avula R, Tosakulwong N, Weigand SD, Senjem ML, Vemuri P, Jones DT, Gunter JL, Baker M, Wszolek ZK, Knopman DS, Rademakers R, Petersen RC, Boeve BF, Jack CR Jr (2011) Altered functional connectivity in asymptomatic MAPT subjects: a comparison to bvFTD. Neurology 77(9):866-874

56. Premi E, Cauda F, Gasparotti R, Diano M, Archetti S, Padovani A, Borroni B (2014) Multimodal FMRI resting-state functional connectivity in granulin mutations: the case of fronto-parietal dementia. PLoS One 9(9):e106500

57. Pievani M, Paternicò D, Benussi L, Binetti G, Orlandini A, Cobelli M, Magnaldi S, Ghidoni R, Frisoni GB (2014) Pattern of structural and functional brain abnormalities in asymptomatic granulin mutation carriers. Alzheimers Dement 10(5 Suppl):S354-S363

58. Dopper EG, Rombouts SA, Jiskoot LC, den Heijer T, de Graaf JR, de Koning I, Hammerschlag AR, Seelaar H, Seeley WW, Veer IM, van Buchem MA, Rizzu P, van Swieten JC (2014) Structural and functional brain connectivity in presymptomatic familial frontotemporal dementia. Neurology 83(2):e19-e26

59. Spina S, Schonhaut DR, Boeve BF, Seeley WW, Ossenkoppele R, O'Neil JP, Lazaris A, Rosen HJ, Boxer AL, Perry DC, Miller BL, Dickson DW, Parisi JE, Jagust WJ, Murray ME, Rabinovici GD (2017) Frontotemporal dementia with the V337M MAPT mutation: tau-PET and pathology correlations. Neurology 88:758-766

60. Jones DT, Knopman DS, Graff-Radford J, Syrjanen JA, Senjem ML, Schwarz CG, Dheel C, Wszolek Z, Rademakers R, Kantarci K, Petersen RC, Jack CR Jr, Lowe VJ, Boeve BF (2018) In vivo 
${ }_{18} \mathrm{~F}-\mathrm{AV}-1451$ tau PET signal in MAPT mutation carriers varies by expected tau isoforms. Neurology 90:947-954

61. Smith R, Puschmann A, Schöll M, Ohlsson T, van Swieten J, Honer M, Englund E, Hansson O (2016) 18F-AV-1451 tau PET imaging correlates strongly with tau neuropathology in MAPT mutation carriers. Brain 139:2372-2379

62. Bevan-Jones RW, Cope TE, Jones SP, Passamonti L, Hong YT, Fryer T, Arnold R, Coles JP, Aigbirhio FA, Patterson K, O'Brien JT, Rowe JB (2018) $\left.{ }_{18} \mathrm{~F}\right] \mathrm{AV}-1451$ binding is increased in frontotemporal dementia due to C9orf72 expansion. Ann Clin Transl Neurol 5:1292-1296

63. Rohrer JD, Woollacott IO, Dick KM, Brotherhood E, Gordon E, Fellows A, Toombs J, Druyeh R, Cardoso MJ, Ourselin S, Nicholas JM, Norgren N, Mead S, Andreasson U, Blennow K, Schott JM, Fox NC, Warren JD, Zetterberg H (2016) Serum neurofilament light chain protein is a measure of disease intensity in frontotemporal dementia. Neurology 87:1329-1336

64. Meeter LH, Dopper EG, Jiskoot LC, Sanchez-Valle R, Graff C, Benussi L, Ghidoni R, Pijnenburg YA, Borroni B, Galimberti D, Laforce RJ, Masellis M, Vandenberghe R, Ber IL, Otto M, van Minkelen R, Papma JM, Rombouts SA, Balasa M, Öijerstedt L, Jelic V, Dick KM, Cash DM, Harding SR, Jorge Cardoso M, Ourselin S, Rossor MN, Padovani A, Scarpini E, Fenoglio C, Tartaglia MC, Lamari F, Barro C, Kuhle J, Rohrer JD, Teunissen CE, van Swieten JC (2016) Neurofilament light chain: a biomarker for genetic frontotemporal dementia. Ann Clin Transl Neurol 3(8):623-636

65. Winter B, Guenther R, Ludolph AC, Hermann A, Otto M, Wurster CD (2019) Neurofilaments and tau in CSF in an infant with SMA type 1 treated with nusinersen. J Neurol Neurosurg Psychiatry. https://doi.org/10.1136/jnnp-2018-320033

66. Galimberti D, Fumagalli GG, Fenoglio C, Cioffi SMG, Arighi A, Serpente M, Borroni B, Padovani A, Tagliavini F, Masellis M, Tartaglia MC, van Swieten J, Meeter L, Graff C, de Mendonça A, Bocchetta M, Rohrer JD, Scarpini E, Genetic FTD Initiative (GENFI) (2018) Progranulin plasma levels predict the presence of GRN mutations in asymptomatic subjects and do not correlate with brain atrophy: results from the GENFI study. Neurobiol Aging 62:245.e9-245.e12

67. Meeter LH, Patzke H, Loewen G, Dopper EG, Pijnenburg YA, van Minkelen R, van Swieten JC (2016) Progranulin levels in plasma and cerebrospinal fluid in granulin mutation carriers. Dement Geriatr Cogn Dis Extra 6(2):330-340

68. Gendron TF, Chew J, Stankowski JN, Hayes LR, Zhang YJ, Prudencio M, Carlomagno Y, Daughrity LM, Jansen-West K, Perkerson EA, O'Raw A, Cook C, Pregent L, Belzil V, van Blitterswijk M, Tabassian LJ, Lee CW, Yue M, Tong J, Song Y, CastanedesCasey M, Rousseau L, Phillips V, Dickson DW, Rademakers R, Fryer JD, Rush BK, Pedraza O, Caputo AM, Desaro P, Palmucci C, Robertson A, Heckman MG, Diehl NN, Wiggs E, Tierney M, Braun L, Farren J, Lacomis D, Ladha S, Fournier CN, McCluskey LF, Elman LB, Toledo JB, McBride JD, Tiloca C, Morelli C, Poletti B, Solca F, Prelle A, Wuu J, Jockel-Balsarotti J, Rigo F, Ambrose C, Datta A, Yang W, Raitcheva D, Antognetti G, McCampbell A, Van Swieten JC, Miller BL, Boxer AL, Brown RH, Bowser R, Miller TM, Trojanowski JQ, Grossman M, Berry JD, Hu WT, Ratti A, Traynor BJ, Disney MD, Benatar M, Silani V, Glass JD, Floeter MK, Rothstein JD, Boylan KB, Petrucelli L (2017) Poly(GP) proteins are a useful pharmacodynamic marker for C9ORF72-associated amyotrophic lateral sclerosis. Sci Transl Med. https://doi.org/10.1126/scitranslmed.aai7866

69. Lehmer C, Oeckl P, Weishaupt JH, Volk AE, Diehl-Schmid J, Schroeter ML, Lauer M, Kornhuber J, Levin J, Fassbender K, Landwehrmeyer B, German Consortium for Frontotemporal Lobar Degeneration, Schludi MH, Arzberger T, Kremmer E, Flatley A, Feederle R, Steinacker P, Weydt P, Ludolph AC, Edbauer D, Otto
M (2017) Poly-GP in cerebrospinal fluid links C9orf72-associated dipeptide repeat expression to the asymptomatic phase of ALS/ FTD. EMBO Mol Med 9(7):859-868

70. Meeter LHH, Gendron TF, Sias AC, Jiskoot LC, Russo SP, Donker Kaat L, Papma JM, Panman JL, van der Ende EL, Dopper EG, Franzen S, Graff C, Boxer AL, Rosen HJ, Sanchez-Valle R, Galimberti D, Pijnenburg YAL, Benussi L, Ghidoni R, Borroni B, Laforce R Jr, Del Campo M, Teunissen CE, van Minkelen R, Rojas JC, Coppola G, Geschwind DH, Rademakers R, Karydas AM, Öijerstedt L, Scarpini E, Binetti G, Padovani A, Cash DM, Dick KM, Bocchetta M, Miller BL, Rohrer JD, Petrucelli L, van Swieten JC, Lee SE (2018) Poly(GP), neurofilament and grey matter deficits in C9orf72 expansion carriers. Ann Clin Transl Neurol 5(5):583-597

71. Oeckl P, Weydt P, Steinacker P, Anderl-Straub S, Nordin F, Volk AE, Diehl-Schmid J, Andersen PM, Kornhuber J, Danek A, Fassbender K, Fliessbach K, German Consortium for Frontotemporal Lobar Degeneration, Jahn H, Lauer M, Müller K, Knehr A, Prudlo J, Schneider A, Thal DR, Yilmazer-Hanke D, Weishaupt JH, Ludolph AC, Otto M (2019) Different neuroinflammatory profile in amyotrophic lateral sclerosis and frontotemporal dementia is linked to the clinical phase. J Neurol Neurosurg Psychiatry 90(1):4-10

72. Woollacott IOC, Nicholas JM, Heslegrave A, Heller C, Foiani MS, Dick KM, Russell LL, Paterson RW, Keshavan A, Fox NC, Warren JD, Schott JM, Zetterberg H, Rohrer JD (2018) Cerebrospinal fluid soluble TREM2 levels in frontotemporal dementia differ by genetic and pathological subgroup. Alzheimers Res Ther 10(1):79

73. Koriath C, Kenny J, Adamson G, Druyeh R, Taylor W, Beck J, Quinn L, Mok TH, Dimitriadis A, Norsworthy P, Bass N, Carter J, Walker Z, Kipps C, Coulthard E, Polke JM, Bernal-Quiros M, Denning N, Thomas R, Raybould R, Williams J, Mummery CJ, Wild EJ, Houlden H, Tabrizi SJ, Rossor MN, Hummerich H, Warren JD, Rowe JB, Rohrer JD, Schott JM, Fox NC, Collinge J, Mead S (2018) Predictors for a dementia gene mutation based on gene-panel next-generation sequencing of a large dementia referral series. Mol Psychiatry. https://doi.org/10.1038/s4138 0-018-0224-0

74. Ng ASL, Tan E-K (2017) Intermediate C9orf72 alleles in neurological disorders: does size really matter? J Med Genet 54(9):591-597

75. Turner MR, Al-Chalabi A, Chio A, Hardiman O, Kiernan MC, Rohrer JD, Rowe J, Seeley W, Talbot K (2017) Genetic screening in sporadic ALS and FTD. J Neurol Neurosurg Psychiatry 88(12):1042-1044

76. Marshall CR, Hardy CJD, Volkmer A, Russell LL, Bond RL, Fletcher PD, Clark CN, Mummery CJ, Schott JM, Rossor MN, Fox NC, Crutch SJ, Rohrer JD, Warren JD (2018) Primary progressive aphasia: a clinical approach. J Neurol 265(6):1474-1490

77. MacLeod R, Tibben A, Frontali M, Evers-Kiebooms G, Jones A, Martinez-Descales A, Roos RA, Editorial C, Working Group 'Genetic Testing Counselling' of the European Huntington Disease N (2013) Recommendations for the predictive genetic test in Huntington's disease. Clin Genet 83:221-231

78. Molinuevo JL, Pintor L, Peri JM, Lleo A, Oliva R, Marcos T, Blesa R (2005) Emotional reactions to predictive testing in Alzheimer's disease and other inherited dementias. Am J Alzheimers Dis Other Demen 20:233-238

79. Crook A, Williams K, Adams L, Blair I, Rowe DB (2017) Predictive genetic testing for amyotrophic lateral sclerosis and frontotemporal dementia: genetic counselling considerations. Amyotroph Lateral Scler Frontotempor Degener 18:475-485

80. Goldman JS (2015) Genetic testing and counseling in the diagnosis and management of young-onset dementias. Psychiatr Clin N Am 38:295-308 
81. Cheran G, Silverman H, Manoochehri M, Goldman J, Lee S, Wu L, Cines S, Fallon E, Kelly BD, Olszewska DA, Heidebrink J, Shair S, Campbell S, Paulson H, Lynch T, Cosentino S, Huey ED (2018) Psychiatric symptoms in preclinical behavioural-variant frontotemporal dementia in MAPT mutation carriers. J Neurol Neurosurg Psychiatry 89(5):449-455

82. Jiang J, Zhu Q, Gendron Tania F, Saberi S, McAlonis-Downes M, Seelman A, Stauffer Jennifer E, Jafar-nejad P, Drenner K, Schulte D, Chun S, Sun S, Ling S-C, Myers B, Engelhardt J, Katz M, Baughn M, Platoshyn O, Marsala M, Watt A, Heyser Charles J, Ard MC, De Muynck L, Daughrity Lillian M, Swing Deborah A, Tessarollo L, Jung Chris J, Delpoux A, Utzschneider Daniel T, Hedrick Stephen M, de Jong Pieter J, Edbauer D, Van Damme P, Petrucelli L, Shaw Christopher E, Bennett CF, Da Cruz S, Ravits J, Rigo F, Cleveland Don W, Lagier-Tourenne C (2016) Gain of toxicity from ALS/FTD-linked repeat expansions in C9ORF72 is alleviated by antisense oligonucleotides targeting GGGGCC -containing RNAs. Neuron 90:535-550

83. DeVos SL, Miller RL, Schoch KM, Holmes BB, Kebodeaux CS, Wegener AJ, Chen G, Shen T, Tran H, Nichols B, Zanardi TA, Kordasiewicz HB, Swayze EE, Bennett CF, Diamond MI, Miller TM (2017) Tau reduction prevents neuronal loss and reverses pathological tau deposition and seeding in mice with tauopathy. Sci Transl Med. https://doi.org/10.1126/scitranslmed.aag0481
84. Arrant AE, Onyilo VC, Unger DE, Roberson ED (2018) Progranulin gene therapy improves lysosomal dysfunction and microglial pathology associated with frontotemporal dementia and neuronal ceroid lipofuscinosis. J Neurosci 38(9):2341-2358

85. Amado DA, Rieders JM, Diatta F, Hernandez-Con P, Singer A, Mak JT, Zhang J, Lancaster E, Davidson BL, Chen-Plotkin AS (2019) AAV-mediated progranulin delivery to a mouse model of progranulin deficiency causes $\mathrm{T}$ cell-mediated toxicity. Mol Ther 27(2):465-478

86. Jadhav S, Avila J, Schöll M, Kovacs GG, Kövari E, Skrabana R, Evans LD, Kontsekova E, Malawska B, de Silva R, Buee L, Zilka N (2019) A walk through tau therapeutic strategies. Acta Neuropathol Commun 7(1):22

87. Lee WC, Almeida S, Prudencio M, Caulfield TR, Zhang YJ, Tay WM, Bauer PO, Chew J, Sasaguri H, Jansen-West KR, Gendron TF, Stetler CT, Finch N, Mackenzie IR, Rademakers R, Gao FB, Petrucelli L (2014) Targeted manipulation of the sortilin-progranulin axis rescues progranulin haploinsufficiency. Hum Mol Genet 23(6):1467-1478

88. She A, Kurtser I, Reis SA, Hennig K, Lai J, Lang A, Zhao WN, Mazitschek R, Dickerson BC, Herz J, Haggarty SJ (2017) Selectivity and kinetic requirements of HDAC inhibitors as progranulin enhancers for treating frontotemporal dementia. Cell Chem Biol 24(7):892-906 